Charles T. Wolfe

Centre for History of Science,

Department of Philosophy and Moral Sciences

University of Ghent

charles.wolfe@ugent.be

\title{
Sensibility as vital force or as property of matter in mid-eighteenth-century debates
}

Penultimate draft

Forthcoming in H.M. Lloyd, ed., Sensibilité: The Knowing Body in the Enlightenment (Oxford:

Voltaire Foundation, expected late 2012)

Sensibilité, Sentiment (Médecine) : la faculté de sentir, le principe sensitif, ou le sentiment même des parties, la base et l'agent conservateur de la vie, l'animalité par excellence, le plus beau, le plus singulier phénomène de la nature, etc.

(Fouquet, Encyclopédie, vol.15, p. 38b).

Sensibility, in any of its myriad realms - moral, physical, aesthetic, medical and so on - seems to be a paramount case of a higher-level, intentional property, not a basic property. That is, while we sometimes suspect or at least pretend to suspect that rocks can sense, we do not consider sensibility an 'atomic' property like shape, size and motion. Higher-level properties like sensibility, thought, memory, desire seem to belong to higher organisms, which leaves room for debate (lizards have recently, as of early 2012, been shown to display learning abilities which lead them to be classified ... higher up the cognitive scale - and of course the idea of a 'higher organism' is itself a piece of folk biology). Now, materialism is often considered to reduce all higher-level properties of our experience to basic ones such as, precisely, shape, size and motion - which was of course the program of the mechanical philosophy in the seventeenth century. This leads to the once-frequent view that materialism is necessarily mechanistic materialism; as a recent entry in a noted secondary source, the Oxford Companion to the History of Modern Science, tells us, 'materialists explain everything in terms of matter and motion; vitalists, in terms of the soul or vital force'. ${ }^{1}$ But anyone who reads a page of Diderot, to name one notable

\footnotetext{
${ }^{1}$ Kathleen Wellman, 'Materialism and vitalism', in The Oxford Companion to the History of Modern Science, editor in chief J.L. Heilbron (Oxford, 2003). Accessed at Oxford Reference Online. September 152011.

http://www.oxfordreference.com.
} 
example, finds a very different constellation from this commonplace opposition between 'matter' and 'sensibility'.

Diderot famously made the bold and attributive move of postulating that matter itself senses, or that sensibility (perhaps better translated 'sensitivity' here, although for the sake of consistency, I will keep the older 'sensibility' ${ }^{2}$ ) is a general or universal property of matter, even if he at times took a step back from this claim and called it a 'supposition'. Crucially, sensibility is here playing the role of a 'booster': it enables materialism to provide a full and rich account of the phenomena of conscious, sentient life, contrary to what its opponents hold: for if matter can sense, and sensibility is not a merely mechanical process, then the loftiest cognitive plateaus are accessible to materialist analysis, or at least belong to one and the same world as the rest of matter.

This was noted by the astute anti-materialist critic, the Abbé Lelarge de Lignac, who, in his 1751 Lettres à un Amériquain, criticized Buffon, the great naturalist, author of the 15-volume Histoire naturelle (and its 7-volume Supplément), but also theorist of generation, for 'granting to the body [la machine, a common term for the body at the time] a quality which is essential to minds, namely sensibility' ('donner à la machine une qualité essentielle aux esprits, la sensibilité'). ${ }^{3}$ This view, here attributed to Buffon and definitely held by Diderot, was comparatively rare. If we look for the sources of this concept, the most notable ones are physiological and medical treatises by prominent figures such as the Edinburgh professor of medicine Robert Whytt (1714-1766), the Swiss, but Göttingen-based Albrecht von Haller (17091777) and the Montpellier physician Théophile de Bordeu (1722-1776), the latter being a key representative of the school we customarily refer to as the Montpellier vitalists. We then have, or so I shall try to sketch out, an intellectual landscape in which new - or newly articulated properties such as irritability and sensibility are presented either as an experimental property of muscle fibres that can be understood mechanistically (Hallerian irritability, as studied recently by Hubert Steinke) or a property of matter itself (whether specifically living matter as in Bordeu and his fellow montpelliérains Ménuret and Fouquet, or matter in general, as in Diderot).

I am by no means convinced that it is one and the same 'sensibility' that is at issue in debates between these figures (as when Bordeu attacks Haller's distinction between irritability and sensibility and claims that 'his own' property of sensibility is both more correct and more fundamental in organic beings), but I am interested in mapping out a topography of the problem

\footnotetext{
${ }^{2}$ In this paper I use the English 'sensibility' for the French sensibilite, as it was the common term at the time, but it should be clear that I mean 'sensitivity': the property of organic beings to sense and respond to stimuli or impressions. Thus Haller's classic paper of 1752 (published in an English translation in 1755) is A treatise on the sensible and irritable parts of animals, not on their 'sensitive' parts. 'Sensibility' in this context is not, say, a term from moral philosophy but an organic term.

${ }^{3}$ To be precise, Lignac is following Condillac's criticism of Buffon ... but he adds that Condillac is just as guilty of error since he 'accorde à l'âme ce qui convient uniquement à la machine'. Lelarge de Lignac, quoted by Condillac, Lettre à l'auteur des Lettres à un Amériquain, annexed to Traité des animaux (1755), in Traité des sensations et Traité des animaux (Paris, 1984), p. 425.
} 
of sensibility as property of matter or as vital force in mid-eighteenth-century debates - not an exhaustive cartography of all possible positions or theories, but an attempt to understand the 'triangulation' of three views: a mechanist, or 'enhanced mechanist' view in which one can work upwards, step by step from the basic property of irritability to the higher-level property of sensibility (Haller); a vitalist view in which sensibility is fundamental, matching up with a conception of the organism as the sum of parts conceived as little lives (Bordeu et al.); and, more eclectic, a materialist view which seeks to combine the mechanistic, componential rigour and explanatory power of the Hallerian approach, with the monistic and metaphysically explosive potential of the vitalist approach (Diderot). It is my hope that examining Diderot in the context of this triangulated topography of sensibility as property sheds light on his famous proclamation regarding sensibility as a universal property of matter: 'la sensibilité est une propriété universelle de la matière'.

\section{Irritability/sensibility as commodity or danger: a Hallerian context}

'La sensibilité fait le caractère essentiel de l'animal' (Haller) ${ }^{5}$

The idea that certain types of organic matter possess reactive or even reflexive properties which were termed 'irritability' and 'sensibility' was, if not 'in the air' in a vague Zeitgeist-like sense, definitely discussed by a variety of figures across early modern Europe, in differing contexts (more or less experimentalist, more or less 'philosophical', more or less prestigious, and so on). While the history of these debates has been largely mapped out, ${ }^{6}$ it is important for my purposes here to provide some reconstruction of this material - not least since it is so difficult to separate 'experimental' work or aspects from 'philosophical' statements or appropriations of something purportedly experimental.

The physician Francis Glisson (1598-1677), great authority on the liver, gall bladder and rickets (in works such as his 1654 Anatomia hepatis), and Regius Professor of Physic at Cambridge, is the locus classicus for the property of irritability - a term which he coined (irritabilitas), as Albrecht von Haller noted. After writing a number of such medical treatises, he produced the Tractatus de natura substantiae energetica, seu de vita naturae... (1672), a metaphysics of living nature in which a rudimentary level of perception was posited as existing in matter itself. Matter contains, he stated, the root of life. Just as particular organs have a

\footnotetext{
${ }^{4}$ Diderot, letter to Duclos of October 10 1765, in Correspondance, ed. Georges Roth, 9 vols. (Paris, 1955-1961), vol. 5, p. 141. As I discuss below, he also calls it a 'general property of matter' and in other texts, casts doubt on this hypothesis...

${ }^{5}$ Haller, 'Sensibilité', Supplément à l'Encyclopédie, ou dictionnaire raisonné des sciences, des arts et des métiers..., 4 vols. (Amsterdam, M.-M. Rey, 1776-1777), vol.4, p. 776a-779b, here, p. 776a (the first sentence of the article).

${ }^{6}$ For the later debates on irritability and sensibility, see Duchesneau, Vila and Steinke; for the earlier appearance of the concept of irritability, see Giglioni.
} 
capacity to react to certain stimuli, so ultimately did matter itself. Irritability was the equivalent at the functional level to the basic property of 'natural perception' in matter. ${ }^{7}$

Albrecht von Haller's concept of irritability, in contrast, has a distinctly experimental flavour - measuring the reaction of parts of the body that did not seem to transmit their stimulation to the 'soul' (which would be tantamount to reflexivity). This is the basic definition of how irritability differs from sensibility: 'I call that part of the human body irritable, which becomes shorter upon being touched; very irritable if it contracts upon a slight touch, and the contrary if by a violent touch it contracts but little. I call that a sensible part of the human body, which upon being touched transmits the impression of it to the soul' 8 This force cannot come from the nerves, since even after they have been cut, muscular fibres can still be irritated, and contract. ${ }^{9}$ Sensations are caused by impressions of objects on the nerves that transmit the impetus to the brain, and from there onto the soul. ${ }^{10}$

Irritability is a quantifiable, experimentally accessible property of the muscle fibres, to be studied mechanistically, in the sense that there will be a correlation between a measurable degree of irritation and a degree of irritation of the fibres: between structure and function. There is no metaphysics of living matter here, at least in appearance. For on the one hand, to be sure, Haller wants to define irritability in such a way as to rule out 'speculative hidden qualities'. ${ }^{11}$ But on the other hand, when pushed as to the reason why certain types of organic matter possess such properties, Haller first attributes it to the 'gluten' within the fibre ('l'irritabilité est en vérité une force particulière à la glu animale ${ }^{, 12}$, although he wavers on this), and then, coming dangerously close to just as vitalist a metaphysics as Glisson (or just as metaphysical a vitalism), attributes this 'vitality' to a hidden force, the vis insita. ${ }^{13}$ Sometimes he is more cautious, and either rejects

\footnotetext{
${ }^{7}$ Guido Giglioni's various essays on Glisson are fascinating studies of this figure and broader issues in the history and philosophy of early modern life science. See, most recently, 'What Ever Happened to Francis Glisson? Albrecht Haller and the Fate of Eighteenth-Century Irritability', Science in Context 21:4 (2008), p. 465-493.

${ }^{8}$ Haller, A Dissertation on the sensible and irritable parts of animals (London, J. Nourse, 1755; reprint, Baltimore, 1936), p. 4-5.

${ }^{9}$ Haller, A Dissertation, p. 39.

${ }^{10}$ Haller, A Dissertation, p. 4.

${ }^{11}$ Hubert Steinke, Irritating Experiments. Haller's Concept and the European Controversy on Irritability and Sensibility, 1750-1790 (Amsterdam/New York, 2005), p. 106.

${ }^{12}$ Haller to Bonnet, March 15 1755, in Otto Sonntag, ed., The correspondence between Albrecht von Haller and Charles Bonnet (Bern, 1983), p. 63.

${ }^{13}$ This intriguing expression does not appear in Haller's early lecture ('Dissertation') on sensibility and irritability, but, as Steinke has noted (Irritating Experiments, p. 106, 123) only in the later Elementa physiologiae and revised editions of the Primae lineae physiologiae, e.g. 'The heart and intestines, also the organs of generation, are governed by a vis insita, and by stimuli. These powers do not arise from the will; nor are they lessened or excited, or suppressed, or changed by the same. No custom no art can make these organs subject to the will, which have their motions from a vis insita; nor can it be brought about, that they should obey the commands of the soul, like attendants on voluntary motion' (First lines of physiology, Translated from the Latin edition, ed. William Cullen [Edinburgh, Macfarquhar and Elliot, 1779], § 409, p 198-199; 1786 edition, vol. I, p. 237-238); the original Latin is in Haller's Primae lineae (originally published 1747), $3^{\mathrm{d}}$ revised and expanded edition (Göttingen: Ap. Vid. Ae. Vandenhoeck, 1765), ch. IX, 'Motus muscularis', § CCCCIX (409), p. 184. The passage is misattributed in Elizabeth L. Haigh's otherwise excellent Xavier Bichat and the medical theory of the eighteenth century, Medical
} 
such considerations as overly philosophical (as when he wants to disqualify La Mettrie's radical appropriations of his work, turning into irritability into a material basis for life), or plays the agnostic, declaring as regards the ultimate cause of irritability that the alleged source 'lies concealed beyond the reach of the knife and microscope'. ${ }^{14}$ Haller the pupil of Boerhaave, the tireless vivisectionist, the inventor of ingenious Newtonian-inspired or otherwise 'geometric' methods and concepts for quantifying the hitherto mysterious properties of life, is himself ... something of a vital force thinker. Positioning him correctly on an échiquier des possibles of eighteenth-century debates combining, as they do, the metaphysics of the soul and the physiology of muscular motion, is easy in some respects, not least given his development of an experimental method and a 'protocol' by which different members of a laboratory can reproduce experiments; but it is difficult when it comes to metaphysical commitments.

For Haller does not want irritability to be presented as a material basis for life in the sense of materialism (as is explicit in his polemic with La Mettrie, in which Haller strikes an ideologically dogmatic tone, and La Mettrie is no less ideological, but definitely playful and ironic). ${ }^{15} \mathrm{He}$ wishes to preserve an independent 'arena' or space of existence for the soul, which is partly contingent on the distinction between irritability - belonging only to the muscles - and sensibility - which has to 'report' to the soul. This is also part of his disagreement with what I shall call below the 'sensibility monism' of vitalists such as Bordeu - a point further extended against Haller by Paul-Joseph Barthez (1734-1806) and other montpelliérains: there is an experimental disagreement, there is a disagreement about the place of philosophical considerations in medical practice ${ }^{16}$, but above all Haller fears a scenario in which matter itself is alive, whether it is an 'irritable matter' - La Mettrie's - or a 'sensible matter' - Bordeu's, that of other vitalists overall, and Diderot's.

Conversely, Haller also disagrees with Robert Whytt, a professor of medicine at Edinburgh, for giving too much room to the soul. Whytt's 1751 work An Essay on the Vital and Other Involuntary Motions of Animals provided a general theory of sensibility, which he viewed as primary with respect to irritability. Whytt associated sensibility and life under the heading of one 'active sentient principle', which however he insisted could not be a mere property of matter itself. ${ }^{17}$ Put differently, irritability presupposes sensibility, so that the latter is not the sole

\footnotetext{
History Supplement (London: Wellcome Institute for the History of Medicine, 1984), p. 52 to Haller's earlier Dissertation. It is also used, without attribution, in the 'Anatomy' article of the Encyclopaedia Londinensis, or, Universal dictionary of arts, sciences, and literature, ed. John Wilkes, vol. 1 (London, Adlard, 1810), p. 563-564. (Thanks to Trevor Pearce, Lucian Petrescu, and Kimberly Garmoe for help with the correct attribution, as well as to Hubert Steinke for his assistance over time...)

${ }^{14}$ Haller, A Dissertation, p. 8.

${ }^{15}$ See Shirley Roe, 'Anatomia animata: the Newtonian physiology of Albrecht von Haller', in Transformation and tradition in the sciences: essays in honor of I. Bernard Cohen, ed. Everett Mendelsohn (Cambridge, 1984), p. 274300, esp. p. 282-284.

${ }^{16}$ Dominique Boury, 'Irritability and Sensibility: Two key concepts in assessing the medical doctrines of Haller and Bordeu', Science in Context 21:4 (2008), p. 521-535.

${ }^{17}$ Robert Whytt, The Works of Robert Whytt (Edinburgh, 1768), p. 128.
} 
exclusive property of the nerves (which were taken to include, not just the conduit, but the 'nervous substance' itself). Rather, it is distributed throughout the body whereas for Haller, as we saw, certain organs and tissue types are insensible. Revealingly for our purposes, Haller more than once assimilated Whytt's view to Stahlian animism (the view that all active functions in the body are somehow the doings of the soul, which, despite being immaterial, is nevertheless controlling the body). ${ }^{18}$ Rather than a monism of an active sentient principle, a variant (like Glisson's, but differently) of a vision of active matter, Haller promotes a structural model, i.e., 'a decentralization of active powers within the animal economy'. ${ }^{19}$ A key implication of this decentralized view is that irritability not have 'anything in common with the soul', as Haller put it. $^{20}$ There is both a functional reason for this (the distinction between two types of properties but also two levels), and a metaphysical reason: both Whytt and La Mettrie pose metaphysical dangers, not so much 'animism or materialism' as they are usually presented, but really, materialism simpliciter, understood as a theory which explains the higher-level in terms of the lower-level.

If the problem is materialism, then it may even be artificial to separate the issue into levels - of matter, of functions, etc. - versus metaphysics: for the concern with levels is a metaphysical concern, with the lower and the higher. As Roger French comments nicely, 'Haller reserves the adjective 'sensible' for those organs or tissues which are capable of communicating to the soul within the brain and there arousing a conscious sensation. He therefore never accepted Whytt's notion of unconscious sensation, a mere lowly animal 'feeling' of the sort that allowed oysters to close up at the approach of danger'. ${ }^{21}$ I hope it is clear that, as in the other episodes of our story, what is at issue is an act of attribution of higher-level properties to a lower-level substrate; and more broadly, the articulation of a concept of living matter in which sensibility is the operative property. Haller himself - not Glisson, not Whytt, not Bordeu, and not Diderot states that 'La sensibilité fait le caractère essentiel de l'animal. Ce qui sent est un animal, ce qui ne sent pas ne l'est point ${ }^{, 22}$ (the latter two thinkers do say such things, but my point is that here it is Haller himself speaking).

The story of irritability and sensibility and their provenance and derivations in this period could be extended much further (with, e.g., Baglivi, Stahl and Bonnet) but as I indicated at the outset, my aim is more limited in the sense that I want to contrast three positions: higher-level

\footnotetext{
${ }^{18}$ The debate (rather acrimonious as it was) continued for years: Whytt replied to Haller in his 'Observations on the Sensibility and Irritability of the Parts of Man and Other Animals: occasioned by Dr. Haller's late Treatise on these Subjects', in Physiological Essays (Edinburgh, Hamilton, Balfour \& Neill, 1755); Haller's later Mémoires on sensibility and irritability are, amongst other things, are a further reply to Whytt. For further analysis see Roger French, Robert Whytt, the soul, and medicine (London, 1969), p. 9, 63f.; Duchesneau, La physiologie des Lumières, chapter 6; Steinke, Irritating Experiments, chapter 3.

${ }^{19}$ Peter Hanns Reill, Vitalizing Nature in the Enlightenment (Berkeley, 2005), p. 131.

${ }^{20}$ Haller, Mémoires sur la nature sensible et irritable des parties du corps animal, 4 vols. (Lausanne, Bousquet, 1756-1760), vol.1, p. 91.

${ }^{21}$ French, Robert Whytt, p. 71.

${ }^{22}$ Haller, 'Sensibilité', Supplément, p. 776a (the first sentence of the article).
} 
properties as mechanistically specifiable properties of certain types of matter (Haller), as features of all living, organized animal matter ${ }^{23}$ - organized as a system of interconnecting 'little lives' (the vitalist view), and lastly, as universal properties of matter itself (materialism, in its Diderotian variant). What is noteworthy so far is that even in the most mechanism-friendly part of the story, Haller's, the risk of slipping into a form of vitalism (for there are many forms of vitalism $!^{24}$ ) is constant, and perhaps made all the more explicit by the way in which figures like Glisson, and later Whytt or Stahl, need to be portrayed as defending purely idealistic, experimentally unsound or ungrounded metaphysics of life, as distinct from a more naturalistically grounded scientific study of organisms.

If Glisson's approach was an attribution of higher-level properties to a lower level he called 'living nature', which was negatively portrayed by Haller so as to guarantee his own experimental, scientific legitimacy while presenting his predecessor as a mysterious-force vitalist $^{25}$ the tension between Haller, Bordeu and the vitalists, and Diderot (who is in more of a 'dialectical' position with respect to the others) shows that a linear portrayal of the debate is a hopeless task, particularly a 'positivistic' account in which thinkers gradually move from metaphysical speculation to 'real science' via experimental trial and error. That is, as I shall indicate in closing, there is a permanent vitalist remainder in the attribution of a mind-like, reactive and/or intentional property to a system of organised matter. Not only are the abovementioned tensions not empirically resolvable (as if it were a matter of deciding between three theories of reflex action, or three disciplinary definitions of the role of physiology); their lack of resolution is also not just ideological (e.g. regarding commitments to a preserved space for the soul, given a naturalistic account of mental life), but metaphysical: the fear of attributing higherlevel properties to a basic substrate, such as matter. Curiously, however, there is no neat separation between orthodox dualists and heterodox materialists here. Notably, because all parties, as I have noted, keep on slipping into various kinds of vitalism - never in the sense of mysterious vital forces like Hans Driesch's entelechies in the late nineteenth and early twentieth centuries, but rather in the sense of the insistence on the uniqueness of the functional properties of certain types of material arrangements (arrangements that form 'organised wholes', a.k.a. corps organisés, or 'organisms' in our vocabulary, or 'animal economies' to use the period's term). Now, where this slippage into monism (since here the vitalist concept, or family of

\footnotetext{
${ }^{23}$ For the case of plants see Brian Garrett, 'Vitalism and teleology in the natural philosophy of Nehemiah Grew', British Journal for the History of Science 36 (2003), p. 63-81.

${ }^{24}$ Charles T. Wolfe, 'From substantival to functional vitalism and beyond, or from Stahlian animas to Canguilhemian attitudes', Eidos 14 (2011), p. 212-235.

${ }^{25}$ Ironically, even Glisson needed to follow this procedure and distinguish his own metaphysics of appetite, perception and living nature from the views of a more monistic, more vitalistic and thus more radical thinker, the Renaissance naturalist Tommaso Campanella. For Glisson, Campanella 'assigned to inanimate material beings more than I would like to, that is, sensation itself' (Giglioni, 'What Ever Happened to Francis Glisson?', p. 479, citing De natura substantiae energetica, 1672, p. 187).
} 
concepts, is one and the same as the monist concept ${ }^{26}$ ) frightens some thinkers, it is on the contrary a desirable outcome to others, not least since it allows for a naturalistically respectable way of dealing with complex properties: what I call sensibility as a 'booster' of matter.

\section{Sensibility as go-between or unifier: vitalist scenarios}

'la doctrine de la sensibilité [est] la même avec celle du vitalisme' (Henri Fouquet, 1803) ${ }^{27}$

When we speak of the Montpellier vitalists, we are referring to the group of physicians and professors of medicine (but also anatomy, botany, etc.) at the Faculty of Medicine at Montpellier, beginning in the mid-eighteenth century; the term 'vitalist' was applied to this group since approximately 1800, and indeed served as a self-description during those decades, although some, like Paul-Joseph Barthez, declared, after most of the influential works - by La Caze, Bordeu et al. - had already been published, that he did not want to be considered as 'le Chef de la Secte des Vitalistes ${ }^{28}$. Given their shared insistence on sensibility as the sole, definitory property of living beings, against Haller's basic distinction between irritability and sensibility, the vitalists could just as easily have been called 'sensibilists'; although in the end, Henri Fouquet, when reflecting retrospectively on their movement in an 1803 work, simply stated that the terms amount to the same thing, since whatever is sensitive (or sensible) is vital ("tout ce qui est sensible est vital"29).

With the vitalists, two major transformations occur with regard to the concept of sensibility as we have encountered it, primarily in its Hallerian presentation.

Empirically - or at a level presented as empirical, experimentally founded, observationally documented, and so on - sensibility is now presented as the primary and general property of living beings (tantamount to life, as Fouquet says above), so that the distinction between irritability and sensibility is jettisoned. To take two examples amongst many, GabrielFrançois Venel (1723-1775), a chemist and physician who was close to Théophile de Bordeu, and authored the long, dense entry 'Chymie' in the Encyclopédie, stated in the 2-line entry 'Irritabilité (Physiologie)', which is mainly a renvoi to Fouquet's long entry 'Sensibilité', that irritability was a word invented by Glisson, then revived 'nowadays by the famous Mr Haller', 'pour désigner un mode particulier d'une faculté plus générale des parties organiques des

\footnotetext{
${ }^{26}$ On sensibility as a monistic property in the 'philosophical medicine' of the montpellierains see Anne C. Vila, Enlightenment and Pathology. Sensibility in the Literature and Medicine of Eighteenth-Century France (Baltimore, 1998), chapter 2.

${ }^{27}$ Fouquet, Discours sur la clinique (Montpellier, Izar \& Ricard, 1803 [an XI]), p. 78, n. 5.

${ }^{28}$ Paul-Joseph Barthez, Nouveaux éléments de la science de l'homme, $2^{\mathrm{e}}$ édition (Paris, Goujon \& Brunot, 1806), p. 98 (= note 18). The first edition appeared in 1778.

${ }^{29}$ Fouquet, Discours sur la clinique, p. 78.
} 
animaux, dont il sera traité sous le nom de sensibilité' ${ }^{30}$ Irritability is just a mode of a more general and primary property, sensibility. Another, brilliant and under-studied Montpellier vitalist figure was Jean-Joseph Ménuret de Chambaud (1733-1815), whom I shall not discuss in detail here. ${ }^{31}$ In his fascinating article 'Economie Animale', Ménuret, too, refers to the property Glisson called irritability, in order to fold it into the more essential property of sensibility. The basic features of life, Ménuret argues, are 'le mouvement \& le sentiment' and these are 'vraissemblablement réductibles à un seul primitif', a yet more basic feature or property, a 'propriété singuliere, la source du mouvement \& du sentiment attachée à la nature organique des principes qui composent le corps'. Ménuret adds that this property depends on a unique type of union between molecules, which Francis Glisson discovered, and named irritability - but in fact, it is really just a mode of sensibility: 'une union telle de ces molecules [...] qui n'est, dans le vrai, qu'un mode de sensibilité'. ${ }^{32}$ Forty years later, Fouquet, in his Discours sur la clinique, sounds the same theme -Haller inappropriately tried to separate irritability from sensibility, on which it is 'essentially and necessarily dependent' : '1'irritabilité, qu' on a prétendu mal à propos isoler de la sensibilité, à qui elle tient essentiellement et nécessairement' ${ }^{33}$

Metaphysically, a major step is taken towards the assertion of a 'monistic' ground in which a certain type of matter, organized matter, is alive and senses. Bordeu repeatedly insists that sensibility is neither strictly mechanical nor a property of the soul: it is immanent in living fibres but decentralized and differentiated, since it takes on a form specific to the function of each organ. It is also, he insists along with other montpelliérains, 'easier to explain than irritability': 'Or, la sensibilité paroît plus aisée à comprendre que l'irritabilité, et elle peut trèsbien servir de base à l'explication de tous les phénomènes de la vie, soit dans l'état de santé, soit dans l'état de maladie'. ${ }^{34}$ As much as the vitalists often say that their type of inquiry is neither as reductive as that of the 'mechanists' (the target varies here, sometimes Boerhaave, sometimes the

\footnotetext{
${ }^{30}$ Venel, 'Irritabilité', Enc. vol.8, p. 909b.

${ }^{31}$ For mysterious reasons Ménuret published mainly under the name Jean-Jacques, although his given name was Jean-Joseph, and his birth date is usually wrongly given as 1733. His Montpellier doctorate in medicine was on biological generation, arguing for epigenesis contra preexistence (De Generatione Dissertatione Physiologica, 1757). Closer inspection of the medical articles in the Encyclopédie, notably by Roselyne Rey in her 1987 thesis, published posthumously in 2000, indicated that Ménuret was a major contributor, whose articles display a high degree of intellectual coherence (Jacques Roger and Jacques Proust had called attention to Ménuret earlier). In Rey's view, if we set aside the case of the 'polygraph' Chevalier de Jaucourt, Ménuret's contribution to the medical articles in the Encyclopédie, from volume VIII onwards (excluding anatomy, surgery, and the material medica) is the largest, most homogeneous set of texts in that work (Rey, Naissance et développement du vitalisme en France de la deuxième moitié du $18^{e}$ siècle à la fin du Premier Empire [Oxford, 2000], p. 72). His articles span volumes VIIIXVII, and were written between late 1758 and 1761, when he was aged 19 to 22. Ménuret spent most of his later career as an 'attending physician' at the Montélimar hospital.

${ }^{32}$ Ménuret, 'Economie Animale’, Enc. vol.9, p. 361.

${ }^{33}$ Fouquet, Discours sur la clinique, p. 78-79, n. 5.

${ }^{34}$ Bordeu, Recherches sur l'histoire de la médecine, in Euvres complètes, 2 vols. (Paris, Caille et Ravier, 1818), vol.2, p. 668.
} 
Italian iatromechanists, sometimes even Haller, despite how far removed he is from strict mechanism), nor as supernatural and un-experimental as that of the animists, Bordeu - in this rather different from Ménuret or Fouquet - is willing to tie his originality to ... Stahlian animism, specifically with regard to sensibility, which he names as the common feature in between his model, Stahl's and Van Helmont's: 'on ne peut nier que ceux qui font de chaque partie du corps un organe ou une espèce d'être ou d'animal qui a ses mouvemens, son action , son département, ses goûts et sa sensibilité particulière n'aient puisé dans la même source que les Stahliens $[\ldots]$, 35

That sensibility is deliberately being construed as an anti-mechanist concept appears notably with Bordeu's choice of 'model organism', the glands, because their secretory and excretory capacity is precisely the type of function that the mechanist model could not do justice to; they respond to stimuli in ways that mechanism cannot specify, but which are also of course independent of soul or will. Bordeu's major work, the Recherches anatomiques sur la position des glandes et sur leur action (1752), is devoted to this topic. In this sense harking back to Glisson (who, as shown by Giglioni, was rather more of an active experimenter than Haller gave him credit for), Bordeu wants to stress that the glands have an innate activity and responsiveness to stimuli which can regulate the 'fluid dynamics' of the exchange between the inside and outside of a gland: this property is sensibility. Consistent with the idea that the glands are so many little lives (which however are indepdent of the soul), Bordeu also describes this responsiveness as dependent on a kind of sensation: 'La sécrétion se réduit donc à une espèce de sensation, si on peut s'exprimer ainsi ; les parties propres à exciter telle sensation passeront, et les autres seront rejetées ; chaque glande, chaque orifice aura, pour ainsi dire son goût particulier ; tout ce qu'il y aura d'étranger sera rejeté pour l'ordinaire'. ${ }^{36}$ Through this property, fibres, tissues, organs, and organ systems carry out sequences of actions according to what Tobias Cheung has called stimulus-reaction-schemes. ${ }^{37}$ For Bordeu, this type of interconnective action is expressed through notions such as 'sympathy' and the 'consensus of the parts', which hark back to the older 'conspiration' (as in Claude Perrault's statement that living bodies different from 'corps inanimés' because the former possess 'la sympathie et la conspiration mutuelle'; he also speaks of 'commerce' and 'besoin mutuel ${ }^{, 38}$ ). In this sense sensibility is also a network concept, which easily shows how it can be picked up together with other concepts of the nervous system by a thinker like Diderot - but it is also a strictly material concept, without either

\footnotetext{
${ }^{35}$ Bordeu, Recherches sur l'histoire de la médecine, in Euvres complètes, vol.2, p. 671.

${ }^{36}$ Bordeu, Recherches anatomiques, § CVIII, in Euvres complètes, vol.1, p. 163. Compare Diderot's 'Pourquoi chaque glande a-t-elle sa sécrétion particulière ? On ne peut guère répondre à cela que par l'irritant, la sensibilité, l'animalité, le goût, la volonté des organes' (Éléments de physiologie, in EEuvres complètes eds. Herbert Dieckmann, Jacques Proust, Jean Varloot [Paris, 1975-], vol.17, p. 387).

${ }^{37}$ Tobias Cheung, 'Omnis Fibra Ex Fibra: Fibre Architectures in Bonnet's and Diderot's Models of Organic Order', Early Science and Medicine 15 (2010), p. 66-104.

${ }^{38}$ Claude Perrault, Essais de physique ou recueil de plusieurs traitez touchant les choses naturelles (Paris, JeanBaptiste Coignard, 1680), vol.1, $2^{\text {nde }}$ partie : Expériences pour l'Éclaircissement de la circulation de la sève des plantes, p. 201.
} 
any intervention of an entity such as the soul, or even of an 'emergentist' conception of hierarchical levels of organization.

However, there is an ambivalence about the ontological status of sensibility (to borrow an expression from Tobias Cheung's discussion of Bordeu). ${ }^{39}$ That is, generally speaking, sensibility is a property of living matter for Bordeu. And his writing focuses on medical entities (rather than questions of basic structure or physiology ${ }^{40}$ ), stressing that the physician is an observer, rather than a quantitative natural philosopher (or experimental physiologist) seeking to discover, say, laws of nervous energy. The physician does not posit the soul, vital principles, or entelechies either. Nevertheless, questions remain. For one, Bordeu, Fouquet and Barthez in particular speak philosophical language at times (as do Bichat and Bernard in the next generations), but especially, they conceive of sensibility in terms of the property of a substance. Whether or not vitalists are like Stahlians (they often say they are not, but as we saw, Bordeu sometimes equates his sensibility concept with Stahl and Van Helmont), they fall somewhere on this spectrum. Consider this somewhat inflated statement by Charles-Louis Dumas (1765-1813), the Dean of the Montpellier medical faculty in the early nineteenth century, who is defending the Montpellier school in a 'wise', retrospective analysis:

Les différentes tendances en médecine sont nées des applications abusives que les Philosophes ont faites tantôt des sciences physiques, tantôt des sciences métaphysiques à la doctrine de l'homme vivant. Ceux qui ont abusé des sciences physiques ont produit la secte ancienne et nombreuse des matérialistes. Ceux qui ont abusé des sciences métaphysiques ont produit la secte non moins ancienne des spiritualistes. Il existe entre elles une $3^{\mathrm{e}}$ classe de physiologistes qui ne rapportent tous les phénomènes de la vie ni à la matière, ni à l'âme, mais à un principe intermédiaire qui possède des facultés différentes soit de l'une soit de l'autre, et qui règle, dispose, ordonne tous les actes de la vitalité, sans qu'il soit mû par les impulsions physiques du corps matériel ni éclairé par les affections morales ou les prévoyances intellectuelles du principe pensant. ${ }^{41}$

As a side note, it is interesting that Dumas uses such pure philosophical language to classify trends in medicine. (Claude Bernard also, as I noted, combines philosophical and physiological language, but when he classifies previous doctrines it is to show how far removed they are from experimental, laboratory science; no such coupure here.) But what does Dumas say? That materialists reduce everything to physics, animists (here termed spiritualists) are overly metaphysical, and finally the vitalists, who do things right, do not reduce vital phenomena either to matter or to the soul. What is this vitalist third way (which we need to grasp if we wish to grasp anything distinctive about Enlightenment vitalism)? If Dumas does not say: we vitalists operate heuristically and have understood that, unlike our predecessors, we should bracket off ontological considerations, Barthez does actually say exactly this, in the second edition of his

\footnotetext{
${ }^{39}$ Cheung, 'Omnis Fibra Ex Fibra', p. 94.

${ }^{40}$ Dominique Boury, 'Irritability and Sensibility', p. 528.

${ }^{41}$ Dumas, Principes de physiologie, ou introduction à la science expérimentale, philosophique et médicale de l'homme vivant (Paris, Crapelet, 1806), vol. 1, p. 296, quoted in Rey, Naissance et développement du vitalisme, p. 386.
} 
Nouveaux éléments, in 1806, in a chapter with the revealing title 'Considérations sceptiques sur la nature du principe vital', where he explains that he 'personifies' the vital principle only 'in order to refer to it more easily' ('pour pouvoir en parler de façon plus commode'); it really has no existence apart from that of the body, 'celle du corps animal qu'il vivifie'. And above all, he adds, 'Je suis, on ne peut pas plus indifférent pour 1'Ontologie, en tant qu'elle est la science des entités $^{, 42}$.

Bordeu had just such hesitations himself with regard to the ontological status of his 'principle', which he calls sensibility. If we recall that sensibility is often described as a 'force conservatrice' by these authors, that is, a type of reactivity or capacity for responsiveness that ensures our survival (e.g. Fouquet defines it as 'la base et l'agent conservateur de la vie ${ }^{, 43}$ and later, Diderot's speaks of sensibility as a 'qualité propre à l'animal, qui l'avertit des rapports qui sont entre lui et tout ce qui l'environne ${ }^{, 44}$ ), it is noteworthy that in a key passage of the Recherches anatomiques - actually a footnote to what is probably the most famous passage of the book, where he introduces the metaphor of the beeswarm to describe organismic unity Bordeu asks if the 'force conservatrice qui veille sans cesse', the self-preserving or conservative force that watches over 'toutes les parties qui vivent' is 'de l'essence d'une portion de la matière, ou un attribut nécessaire de ses combinaisons ? ${ }^{45}$. It is not possible to reconstruct Bordeu's thinking further and provide a definite answer to his question. But we can learn from this that the vitalist doctrine of sensibility poses itself the question, both of the ontological status of this property overall, and of the specific situation that obtains, with regard to sensibility as (general) property of matter or (more restrictively) of organisation.

Vitalist sensibility - Bordeu's and others' - is not a merely mechanical-reaction property, because of its 'network' dimension, its way of explaining and at the same time implying the consensual, sympathetic interaction of the organic parts understood as little lives. I have mentioned this idea earlier but only in passing; suffice it to say here that it is a core idea of Montpellier vitalism, consisting in the following: the organism (living body, animal economy) is not a set of inanimate parts but of organs understood as so many little lives. Ménuret speaks of 'la vie générale formée par les vies particulières des organes ${ }^{46}$; Fouquet says that 'chaque organe sent ou vit à sa maniere, \& le concours ou la somme de ces vies particulières fait la vie en général'. The point was perhaps made best of all in an almost unknown text, a medical thesis on irritability defended at Montpellier in 1776 by a certain Mr 'D.G.' (who further research identifies as Jean Charles Marguerite Guillaume de Grimaud): this applies down to the level of

\footnotetext{
${ }^{42}$ Barthez, Nouveaux éléments, $2^{\text {nd }}$ edition, vol.1, p. 107, 99 and note 17 on Chapter 3, p. 96 (it can be confusing that the notes added to this edition have their own pagination, also in Arabic numerals: thus the reader can read about the metaphysics of substance on p. 96 of the main text and not find 'ontology', but if she turns to later sections where the page numbers restart, these sections appear).

${ }^{43}$ Fouquet, 'Sensibilité', Enc. vol.15, p. 38b.

${ }^{44}$ Diderot, Éléments de physiologie, in Euvres, vol.17, p. 305.

${ }^{45}$ Bordeu here concedes that he must be content here with analogies, 'expressions métaphoriques, comparaisons'. Bordeu, Recherches anatomiques, § CVIII, note, in Euvres, vol.1, p. 163, emphasis mine.

${ }^{46}$ Ménuret, 'Economie Animale', Enc. vol.11, p. 361b ; Fouquet, 'Sensibilité', Enc. vol.15, p. 42b.
} 
the so-called molecules composing each organ, 'la vie de chaque organe du corps animé n'est point une vie simple mais elle est réellement le produit d'autant de vies particulières qu'il est de molécules vivantes qui entrent dans la composition de cet organe'. ${ }^{47}$ This is neither mere aggregation of matter nor mechanical relations between parts defined by shape, size, motion (and position).

However, like irritability, sensibility as discussed here is exclusively material and thus without any 'transcendent' or 'spiritual' dimension. ${ }^{48}$ That is, as d'Holbach put it, whether sensibility is 'une qualité qui se communique comme le mouvement et qui s'acquiert par la combinaison', or instead 'une qualité inhérente à toute matière', in both cases it cannot belong to 'un être inétendu, tel que l'on suppose l'âme humaine,49. Further, sensibility has both a reductionist dimension (in this not so far removed from Haller's irritability) and a holistic dimension: the former, because there is a specific analysis of types of tissue, of the structure and function of glands, and so on; the latter, because what is then stressed is the way in which organs interact and produce 'systemic' or 'organisational' properties. The more reductionist vision is apparent when Fouquet, when he underscores the compatibility of Haller's system and the system of sensibility (i.e. his own and Bordeu's), speaks both of the 'consensus of organs' and of 'their location' (i.e. spatial, positional information) ${ }^{50}$ Or, to take an example from a different, but familiar author, La Mettrie in his 'materialist' rendition of the concept of irritability, also insists that each fibre of animal bodies moves according to an inherent principle, but with a less holist result than e.g., what Bordeu (or Diderot) will promote: 'chaque petite fibre, ou partie des corps organisés, se meut par un principe qui lui est propre, et dont l'action ne dépend point des nerfs, comme les mouvements volontaires; puisque les mouvements en question s'exercent, sans que les parties qui les manifestent aient aucun commerce avec la circulation'. ${ }^{51}$ What is different in Fouquet's sense of the consensus/conspiration/sympathy of organic parts is that it is a structural view. For instance, he also speaks of the 'action économique de la sensibilité', with the term 'economic' being reminiscent of the technical term 'animal economy', i.e., a system of interdependent relations over and beyond ordinary aggregation of matter, bringing together various 'lives' (active organs) in a manner he describes as 'harmonie, symmétrie \& arrangement'. However, Fouquet - like Bordeu - remains agnostic about whether this harmony,

\footnotetext{
${ }^{47}$ Jean Charles Marguerite Guillaume de Grimaud, Essai sur l'irritabilité (Avignon, Bonnet frères, 1776), p. 12 (italics in original). I first encountered this text, quoted (only as 'D.G.'; I've added the attribution) in Philippe Huneman, “Animal Economy': Anthropology and the Rise of Psychiatry from the Encyclopédie to the Alienists', in The Anthropology of the Enlightenment, eds. Larry Wolff and Marco Cipolloni (Stanford, 2007), p. 262-276, 390394 (notes), here, p. 390 n. 2.

${ }^{48}$ Boury, 'Irritability and Sensibility', p. 529.

${ }^{49}$ D’Holbach, Système de la Nature, II, viii, in d'Holbach, Euvres philosophiques, ed. J.-P. Jackson, vol.1 (Paris, 1998), p. 229-230.

${ }^{50}$ Fouquet, 'Sensibilite', Enc. vol.15, p. 51a. It is important to remember that articles like these, which came out in the 1765 'batch' of the Encyclopédie, are thus fifteen years posterior to Bordeu's Recherches anatomiques.

${ }^{51}$ This is La Mettrie's comment after listing ten experiments proving mind-body interaction (Julien Offray de La Mettrie, L'Homme-Machine [Leiden, E. Luzac, 1748], p. 74; ed. A. Vartanian [Princeton, 1960], p. 181-182).
} 
this 'economic action' is the result of interaction or just of an additive accumulation of parts ('le concours ou la somme de ces vies particulieres'), ${ }^{52}$ closer to La Mettrie's vision.

It is hard to reduce vitalist sensibility to a straightforward claim or set of empirical points, whether we take our bearings for these from the history of medicine, of hybrid discourses 'of the nerves', passions and spirits, or of course from philosophy. Yet at the same time the Montpellier vitalists are consistent over time with a set of claims they make with respect to this property, even if they can be more or less Stahlian, more or less Hallerian-compatible, more or less materialism-friendly. There is a general sensibility monism here which makes it all the more natural that Diderot found it such an appealing concept - or an appealing medico-theoretical construct to turn into a concept, in order to challenge the Cartesian dualism laid out by the character D'Alembert in the first dialogue of the Rêve de D'Alembert. ${ }^{53}$

\section{Sensibility as a booster-property of matter in Diderot}

'le vivant et l'animé, au lieu d'être un degré métaphysique des êtres est une propriété physique de la matière' (Diderot) ${ }^{54}$

In the very first paragraph of Diderot's 1769 'dialogue' Le Rêve de D'Alembert, which was one of his two personal favourites amongst his works (the other being a mathematical essay on probabilities $^{55}$ ), the character D'Alembert, who is a partisan of substance dualism, challenges the character Diderot - a materialist, as it happens - to account for the existence of consciousness and thought, and in doing so introduces the problem of sensibility as a property. Referring to a discussion that seems to have taken place before the text begins, he declares to Diderot, 'car enfin cette sensibilité que vous lui substituez, si c'est une qualité générale et essentielle de la matière, il faut que la pierre sente' ${ }^{56}$ That is, if the character Diderot thinks he can successfully

\footnotetext{
${ }^{52}$ Fouquet, 'Sensibilité', Enc. vol.15, p. 42 b.

${ }^{53} \mathrm{I}$ am not claiming there is some traditional relation between the 'practice' of physicians and the 'conceptualization' of a philosopher, here Diderot. Both because these physicians are very much médecinsphilosophes, sometimes self-proclaimed, and their writings can bristle with philosophical references (especially Barthez who revised his Nouveaux elements with more and more empiricist references, pasting in Bacon and Hume in a desperate hope that his treatise would turn into a perfect piece of empiricism); and of course, because Diderot operates across multiple registers - chiefly, for present purposes, an experimental-naturalistic novel or dialogue, Le Rêve de D'Alembert, and a naturalistic proto-work, the Éléments de physiologie, which stand in a fertile but ambiguous relation to each other. The well-known fact that Bordeu is also a character in the Rêve should illustrate the difficulty of traditional distinctions (without it having to imply that Diderot was the first postmodern, or practicioner of intertextuality...).

${ }^{54}$ Diderot, 'Animal', Enc. vol.1, p. 474a (quoting Buffon, Histoire générale des animaux, 'Comparaison des animaux et des végétaux').

${ }^{55}$ Diderot, Correspondance, vol.9, p. 126; cf. 'Fragments dont on n'a pas pu retrouver la véritable place', in Diderot, Euvres, vol.17, p. 223. The Rêve was unpublished during Diderot's lifetime (he gave one copy to Catherine the Great as a gift).

${ }^{56}$ Diderot, Rêve de D'Alembert, in Euvres complètes, vol.17, p. 90.
} 
defend thinking matter, or a variant of it, by reconfiguring it as sensing matter, the character D'Alembert responds: then you'll also have to grant that rocks can sense. Sensibility is hence present from the first lines of the text, and the word ('sensibilite') is used a total of 37 times.

How can we define the steps taken from Haller, Bordeu et al. to Diderot? There are two equally trivial ways to proceed, which are roughly symmetrical, and focus respectively on two different works by Diderot, which indeed have a very different status. One is to view Diderot as a kind of proto-Bachelardian poet-metaphysician of the cosmos, ${ }^{57}$ as manifest in the Rêve with its 'Dans Jupiter ou dans Saturne, des polypes humains! ${ }^{58}$, and thus present his contribution as a kind of leap into associative freedom beyond the constrained empirical studies of Haller and others. Sometimes this speculative dimension, in which Diderot's scientific imagination can reach conceptual 'places' that science cannot, is described as a kind of science-fiction, or more aptly, as 'a thought experiment on sensibility', in Anne Vila's terms, although she notes that it is a thought experiment which instantly has material effects and conversely, itself is 'materialized'. 59

The other approach focuses on the Éléments de physiologie (an unfinished text which Diderot worked at in the late 1770s), and views Diderot as a commentator on scientific studies of sensibility, who remains at the level of fragments, unable to provide his own scientific theory. Namely, if Haller's physiology contributed the idea of a combinatorial system composed of the structural elements of the organism, which amounted to a system of functional vital properties corresponding to various level of organic integration, ${ }^{60}$ Diderot is, on this view, either a mere commentator on such concepts, or a naturalistically inclined philosopher seeking to accumulate information to support his general vital-materialist views.

A more sympathetic or expansive version of this view, which grants Diderot more originality, is to view his reflections on irritability and sensibility, fibres and organs, bodies and networks as a genuine expansion of vitalist organicism, in the direction of a total 'science of man', understood as an integrated doctrine of the physical and the moral. And it has been observed by commentators at least as far back as Yvon Belaval that the Éléments, which Diderot probably intended to publish if he had been able to continue, closely resembles contemporary treatises on 'L'Homme' such as those by Marat or Le Camus. ${ }^{61}$ Indeed, there is a careful articulation of Haller, Bordeu and Barthez in the Éléments (along with Whytt and additional

\footnotetext{
${ }^{57}$ As in Ian Alexander, 'Philosophy of Organism and Philosophy of Consciousness in Diderot's Speculative Thought', in Studies in Romance Philology and French Literature Presented to John Orr (Manchester, 1953), p. 121.

${ }^{58}$ Diderot, Rêve, in Euvres, vol.17, p. 125.

${ }^{59}$ Vila, Enlightenment and Pathology, p. 74. For my discussion of this issue see 'Le rêve matérialiste, ou 'Faire par la pensée ce que la matière fait parfois", Philosophiques 34:2 (2007), p. 317-328.

${ }^{60}$ François Duchesneau, 'Diderot et la physiologie de la sensibilité', Dix-huitième siècle 31 (1999), p. 195-216, here p. 197. In the later portions of his article Duchesneau seems to defend Diderot's originality as a contributor to medico-physiological theory.

${ }^{61}$ Belaval, Études sur Diderot (Paris, 2003), p. 257.
} 
figures I shall not discuss); the title itself is, of course, the same as that of the French translation of Haller's 1747 Primae lineae physiologiae: Elémens de physiologie (first translation by Tarin, 1752, second translation by Bordenave, 1769).

Diderot brings together a mechanistically oriented account of a structural relation between solid parts (from Haller), the more holistic sense of an integrated network of sensibility/sympathy (from Bordeu and Barthez) and various other theories of organic matter concerning what we might call 'vital minima', that is, the minimal constituents of organic life which are themselves 'alive' and possessed of animate properties. ${ }^{62}$ And he collapses any residual dualist distinction between irritability and sensibility (which after all, in Haller and in Whytt although in completely different ways, had served to preserve a concept of soul): 'En général dans l'animal et dans chacune de ses parties, vie, sensibilité, irritation' ${ }^{63}$ Differently from Whytt or Bordeu and his colleagues who had to insist on a quasi-metaphysical primacy of sensibility, Diderot just renders them identical:

Cette force d'irritabilité est différente de toute autre force connue; c'est la vie, la sensibilité ; elle est propre à la fibre molle ; elle s'affaiblit et s'éteint dans la fibre qui se racornit ; elle est plus grande dans la fibre unie au corps que dans la fibre qui en est séparée. Cette force ne dépend ni de la pesanteur, ni de l'attraction, ni de l'élasticité. ${ }^{64}$

The life of the animal, ' 1 'animal entier', is the composite of the life of each organic component, interacting in a relation of 'sympathy', which sometimes is not dependent on any centre, any 'controller' at all: 'Voilà donc des organes sensibles et vivants, accouplés, sympathisant et concourant à un même but sans la participation de l'animal entier'. ${ }^{65}$ This raises the question of the unity of the organism (in the Reve, the unity of the self, which Mlle de Lespinasse worries about - to which the character Bordeu replies precisely with a doctrine of organismic unity, that is, you are yourself because of the individuality of your body or organisation). After all, if an organism is a sum of many lives, whether this is an additive sum or one that involves qualitative shifts, where is the limit? This is another one of the difficult questions which neither Diderot nor Bordeu - both of whom pose it - resolve to anyone's satisfaction, including their own. One recalls that Bordeu introduced the image of the beeswarm as a metaphor of organic unity, and Diderot, although he expands on it and adds other metaphors including the spiderweb and the harpsichord (for the vibrating 'strings' of the nervous system), does not present it as anything other than that. Now, my purpose here is not to reconstruct a possible 'materialist theory of the self', in Diderot and others, ${ }^{66}$ but rather to inquire into the extent to which a concept like sensibility functions as a 'booster' for the materialist - a

\footnotetext{
${ }^{62}$ Charles T. Wolfe, 'Endowed molecules and emergent organisation: the Maupertuis-Diderot debate', Early Science and Medicine 15 (2010), p. 38-65.

${ }^{63}$ Diderot, Éléments de physiologie, in Euvres, vol.17, p. 449.

${ }^{64}$ Diderot, Éléments de physiologie, in Euvres, vol.17, p. 308.

${ }^{65}$ Diderot, Éléments de physiologie, in Euvres, vol.17, p. 501.

${ }^{66}$ I attempt an initial presentation of the problem in my 'Éléments pour une théorie matérialiste du soi', in La Circulation entre les savoirs au siècle des Lumières. Hommages à Francine Markovits, ed. François Pépin (Paris, 2011), p. 123-149.
} 
functional booster, at the level of physiology and medicine, and an ontological booster, with respect to levels of organization, emergence and reduction.

Yet we must not lose sight of the fact that this appropriation of the concept of sensibility is a key part of Diderot's attempt to articulate organic unity, as something different from the unity of machines, or that of the universe as a whole. And, crucially for the specifically biomedical context I have sketched, this attempt is not generically metaphysical or inspired by classic texts in the history of philosophy, but is particularly close to medical texts such as Bordeu's; as Martyn Lloyd suggests, 'for the discourse of sensibility the master discourse was medicine' ${ }^{67}$ Even if the idea of matter as possessing animate features can be viewed as something Leibnizian (as a 'materialisation of the monad', as it is sometimes described, or a kind of panpsychism, which La Mettrie had already recognized as a danger: 'Les leibniziens, avec leurs Monades, ont élevé une hypothèse inintelligible. Ils ont plutôt spiritualisé la matière, que matérialisé l'âme ${ }^{68}$ ) or as harking back to Renaissance matter theory as in Campanella, ${ }^{69}$ it has a very particularly medical, embodied flavor here. Consider Diderot's approach to the unity of animals or organisms he calls 'continuity' as opposed to the merely spatial 'contiguity' that exists between heaps of matter: 'Sans la sensibilité et la loi de continuité dans la contexture animale, sans ces deux qualités l'animal ne peut être un'. ${ }^{70}$ Biology and medicine or metaphysics were hard to separate with respect to sensibility as late as the mid-nineteenth century, as noted by Littré: 'la sensibilité ou fonction des nerfs [...] est un dernier terrain que la théologie et la métaphysique disputent à la biologie'. ${ }^{71}$

That sensibility is a medical concept with an expansive conceptual potential can also be seen in another way: Diderot (and partly La Mettrie before him, for whom 'irritability' is the general monistic term rather than 'sensibility') sees that a concept such as sensibility allows him to conceptually integrate the reactivity and representational capacity of mind (the nervous system, the brain as a 'book which reads itself', as Diderot puts $\mathrm{it}^{72}$ ) while maintaining a thoroughgoing naturalism - there are no properties which are not properties of natural beings subject to causal processes as specified in the natural sciences (whatever these may be: thus the naturalism of a Hobbes or a d'Holbach, who seem to be intuitively physicalists, is very much a reduction to the physical properties of matter, while the naturalism of a Gassendi, a Diderot or, a

\footnotetext{
${ }^{67}$ Lloyd, 'Sensibilité, Embodied Epistemology and the Encyclopédie', this volume.

${ }^{68}$ La Mettrie, L'Homme-Machine (1748), p. 2; ed. Vartanian (Princeton, 1960), p. 149.

${ }^{69}$ Diderot provides some indication as to the Leibnizian provenance of his idea of sensibility as a universal property of matter in his Encyclopédie entry 'Leibnitzianisme', where he associates Aristotelian entelechies, monads, and 'sensibility [as] a general property of matter' (Enc. vol.9, p. 371a). As in other cases, his source is Johann Jakob Brucker's 1744 Historia critica philosophice. Belaval notes that the publication of Jean-Baptiste Robinet's Leibnizian Philosophie de la nature in 1765 - the year of the letter to Duclos - may have led Diderot to the idea of consideration of animate parcels of matter (Études sur Diderot, p. 334 n. 3).

${ }^{70}$ Diderot, Éléments de physiologie, in Euvres, vol.17, p. 307.

${ }^{71}$ Émile Littré, 'De la physiologie' (a review essay on Johannes Müller's Manuel de Physiologie), Revue des deux mondes 14 (1846), p. 200-237, here, p. 229.

${ }^{72}$ Éléments de physiologie, in Euvres complètes, vol.17, p. 470.
} 
few decades later, an Erasmus Darwin is a reduction to matter conceived as the bearer of vital, animate properties, typically attributed to minimal components of matter named 'semences', 'semina rerum', or 'molecules ${ }^{, 73}$ ). This naturalism has been interpreted in various ways by Diderot commentators in recent decades: as 'monism', or 'holism' or again 'emergentism' these contemporary terminological decisions do not modify the fundamental intuition that (i) matter is 'one', a unified whole (both at the level accessible to our measuring instruments and at a metaphysical level: Nature makes no leaps), (ii) properties such as sensibility, consciousness, memory, desire, instinct are 'just there' - no room for external world skepticism, 'il n'y a point de plaisir senti qui soit chimérique ${ }^{, 74}$ - and as such belong to the material whole as stated in (i).

Diderot is less willing to commit to a definitive position regarding (iii) whether these properties are universal properties of matter, as he often says (we might also say 'basic properties', thinking of Ménuret's insistence that movement and sensibility reduce to 'un seul primitif ${ }^{\text {75)}}$, or properties only of organised wholes: 'La sensibilité, propriété générale de la matière ou produit de l'organisation'. 76 The first view certainly fulfils the requirements of a materialist metaphysics, and is pleasingly immanentist ... except that it is also a potentially 'panpsychist' view in which tiny parcels of matter are themselves said to think, feel, remember and react (recall La Mettrie's warning about 'spiritualising matter'); the second view offers the advantage of a hierarchical arrangement in which there are levels of organisation - today we might say 'levels of complexity' - which are interrelated within a general material whole.

Here we leave specifically Bordevian or vitalist territory in Diderot and return to metaphysics. In the earlier Pensées sur l'interprétation de la nature (1753), Diderot had reflected on the quasi-aporia of the relation between living matter and dead matter, and put forth a series of 'queries' (somewhat reminiscent of the Queries which followed Newton's Opticks) which tended to challenge the distinction between these two states. Whether we view this as an empirical or a metaphysical issue in Diderot, he definitely insists that the distinction is false inasmuch as what is alive is constantly in a process of fermentation and corruption, and what is dead is conversely in a process of being assimilated into life like the marble of the statue, ground into earth, growing into plants and eaten by animals, and so on - a process he or d'Holbach coined a term for, 'animalisation'. As Diderot says in his marginal commentary on Franz Hemsterhuis' Lettre sur l'homme (1773-1774): 'Quand je naquis, je ne sentais que sur une longueur d'environ dix-huit pouces au plus. Comment suis-je parvenu avec l'âge à sentir sur une longueur de cinq pieds et quelques pouces ? J'ai mangé. J'ai digéré. J'ai animalisé. J'ai fait passer par l'assimilation des corps bruts de l'état de sensibilité inerte à l'état de sensibilité

\footnotetext{
${ }^{73}$ On vital minima in a materialist context see my essay, 'Endowed molecules and emergent organization: the Maupertuis-Diderot debate'.

${ }^{74}$ Diderot, Letter III to Falconet, in Le pour et le contre (correspondance avec Falconet), in Euvres complètes, vol.15, p. 9 .

${ }^{75}$ Ménuret, 'Economie Animale’, Enc. vol.11, p. 361 b.

${ }^{76}$ Diderot, Rêve, in Euvres, vol.17, p. 105.
} 
active'. ${ }^{77}$ So animalisation is a process which ensures that matter is sensible, since it is constantly moving from inert to active; and the new distinction between inert sensibility and active sensibility can help resolve some of the above difficulties. ${ }^{78}$ But isn't this just another version of dead matter versus living matter? Or (to point to a different problem), monism seems to indicate that Diderot should opt for one kind of matter, not two, and then claim that this matter senses. But - as he notices in his critique of Maupertuis' panpsychism - it seems to be a mistake (although of what sort is not clear: empirical? metaphysical?) to endow the element - the 'molecule' - with the properties of the whole - l'organisation, or here, to endow matter with the properties of organized wholes. ${ }^{79}$

Again, what is the status of sensibility? Diderot's dilemma, or at least his ontological decision, returns here: 'La sensibilité, propriété générale de la matière ou produit de l'organisation'. ${ }^{80}$ He addresses this in a variety of texts - 'speculative' ones such as the Rêve, 'experimental' ones such as the Éléments (however much the distinction between speculative and experimental may be shopworn and of limited use here), letters to Sophie Volland (October 1759) and better-known, to Duclos (October 1765), commentaries and critiques on other thinkers such as Hemsterhuis and Helvétius. Before trying to achieve some resolution on the issue by way of conclusion, let me try and map out the situation in Diderot.

First, there is no clear-cut distinction between different texts which represent different positions on the issue, as some have suggested. Granted, the Reve is more speculative than the Éléments, but even in the latter, he asks, 'Pourquoi ne pas regarder la sensibilité, la vie, le mouvement comme autant de propriétés de la matière : puisqu'on trouve ces qualités dans chaque portion, chaque particule de chair ? ${ }^{, 81}$ Yet, second, it is clear that different viewpoints are adopted, not some kind of perpetual polyphony. Thus in the Réfutation d'Helvétius, four years after the Rêve, Diderot calls the general sensibility of matter a mere 'supposition', which is not sufficient for 'good philosophy', and admits that 'la liaison nécessaire de ce passage m'échappe'. ${ }^{82}$ That is, how can inert matter become active matter? This is why epigenetic processes such as embryo growth in the egg are so metaphysically 'pregnant', so to speak, for Diderot: because they provide evidence that out of exclusively material layers something like life (a.k.a. sensibility) emerges. Hence sciences such as the nascent biology of the eighteenth century but also chemistry and medicine are of great importance, if not filling out the blanks in this 'passage' so that all necessary causal links are made explicit, at least in articulating it as a material process.

\footnotetext{
77 Observations sur Hemsterhuis, in Diderot, Euvres, vol. 24, p. 304.

${ }^{78}$ See the brief but useful discussion in Colas Duflo, 'Sensibilité', in L'Encyclopédie du Rêve de D'Alembert de Diderot, eds. Jean-Claude Bourdin, Colas Duflo et al. (Paris, 2006), p. 347-352.

${ }^{79}$ Charles T. Wolfe, 'Endowed molecules and emergent organisation', p. 57, 65.

${ }^{80}$ Diderot, Rêve, in Euvres, vol.17, p. 105.

${ }^{81}$ Diderot, Éléments de physiologie, in Euvres, vol.17, p. 333.

${ }^{82}$ Réfutation d'Helvétius, in Cuvres, ed. L. Versini, vol.1 : Philosophie (Paris, 1994), p. 297-298.
} 
If Diderot's 1759 and 1765 letters treat us to some real phantasmagorias, with the idea of matter possessing sensation for all eternity ('Le sentiment et la vie sont éternels. Ce qui vit a toujours vécu, et vivra sans fin. La seule différence que je connaisse entre la mort et la vie, c'est qu'à présent, vous vivez en masse, et que dissous, épars en molécules, dans vingt ans d'ici vous vivrez en détail') so that the molecules of lovers buried side by side will join together after the deaths of their individual organisms, and less romantically, the description of the animal as a 'laboratory' in which sensibility shifts from inert to active, ${ }^{83}$ in the last texts, including the Eléments, the problem of whether sensibility is a universal property of matter indeed becomes strictly ... experimental, with considerations of flayed vipers, the trunks of eels and sectioned grass snakes:

Je serai tenté de croire que la sensibilité n'est autre chose que le mouvement de la substance animale, son corollaire; car si j'introduis la torpeur, la cessation du mouvement dans un point, la sensibilité cesse. [...] La sensibilité de la matière est la vie propre aux organes. La preuve en est évidente dans la vipère écorchée et sans tête, dans le tronçon de l'anguille et d'autres poissons, dans la couleuvre morcelée, dans les membres séparés du corps et palpitants, dans la contraction du coeur piqué. ${ }^{84}$

And he explicitly uses the language of 'demonstration': 'On en viendra quelque jour à démontrer que la sensibilité ou le toucher est un sens commun à tous les êtres. Il y déjà des phénomènes qui y conduisent $[\ldots] .{ }^{85}$ Sensibility as the life 'propre aux organes', sensibility as a sense which is 'commun à tous les êtres': we are back at a vitalist vision of sensibility as the life of a system of organs.

\section{Conclusion}

Diderot adopts a vitalist solution to the series of metaphysical aporias concerning sensibility and matter. He did not opt for the straightforward solution that sensibility results from organization, instead stating, even when discussing particulars such as grass snakes (much as La Mettrie had combined the metaphysics of irritability with the case of lizards in one passage), that sensibility is a property of matter. As Timo Kaitaro has put it, if sensibility results from organization one then has the problem of explaining this organization, whereas if matter possesses some vital properties, an elementary form of sensibility, this could be used in explaining its tendency to form organized wholes ${ }^{86}$ And, as we saw with respect to Fouquet,

\footnotetext{
${ }^{83}$ Diderot, respectively letters to Sophie Volland, October 171759 and to Duclos, October 10 1765; Correspondance, vol.2, p. 283-284; vol. 5, p. 141.

${ }^{84}$ Diderot, Éléments de physiologie, in Euvres, vol.17, p. 305-306. Jacques Chouillet suggests that Diderot wrote the Principes philosophiques sur la matière et le mouvement (1770) to empirically resolve this problem of the 'passage' from the inert to the active, even though there is no discussion of sensibility or life in the text; but there is another, even more fundamental act of 'monistic collapse', of the difference between inertia and motion (Diderot poète de l'énergie [Paris, 1984], p. 54).

${ }^{85}$ Diderot, Éléments de physiologie, in Euvres, vol.17, p. 308.

${ }^{86}$ Timo Kaitaro, 'Man is an admirable machine' - a dangerous idea ?' in La lettre de la Maison française d'Oxford 14 (2001), special issue on Mécanisme et vitalisme, p. 105-121, here, p. 113.
} 
Bordeu and La Mettrie's versions of the organism as composed of little lives, there are also different degrees in their articulations of organizational 'wholeness'. The aporias of living and dead matter, inert and active sensibility and generally, sensibility as ontologically irreducible or as a result of certain types of organization, may or may not be fully resolved, even if it is hopefully clear that the subtle vitalist reflections did not just arrive at Diderot's 'science-fiction' or phantasmagorias as a terminus. But we have seen that the property of sensibility acts as a conceptual booster - the materialist's privileged route of access to 'what lies higher', as seen with the dialogue between Diderot and D'Alembert - and one which is of specifically medical origin.

In the end, for Diderot rocks do not sense except in the rather 'God's-eye', Spinozist sense that in the long run, they too will be 'animalized'. Organisms sense; sensibility is the definitory property of organic matter. Thought cannot result from the mere spatial proximity of molecules, the contiguity of matter; it results from sensibility ('la pensée est le résultat de la sensibilité'), which is inert in 'corps bruts' like rocks, and active in living bodies, by being assimilated with 'une substance animale vivante ${ }^{87}$. In addition to the rather technical considerations we have encountered concerning how organisms hang together, it is important to remember that if D'Alembert grants Diderot's claim that matter can sense - that sensibility is a universal or general property of matter - he will have granted everything, for Diderot, in this extending an empiricist insight which nowhere appears as radically as in his version, has collapsed all cognitive functions into modes of sensation: 'Il n'y a d'inné que la faculté de sentir et de penser ; tout le reste est acquis', or as d'Holbach has it in the Système de la nature (a work on which Diderot was an active collaborator), 'Qu'est-ce que penser, jouir, souffrir, sinon sentir ? ${ }^{, 88}$

I have not tried, as is often done, to reconstruct a problem and its solutions, e.g., 'how did these thinkers move from a mechanistic model to one recognizing the complexity of sensibility as a feature, either of the self-regulation of organisms and/or of the nervous system?'. Rather, I have suggested a topography of the problem of sensibility as property of matter or as vital force in the mid-eighteenth century, in the tangle of disciplines and discourses devoted to the nature of living, biological entities - not an exhaustive cartography of all possible positions or theories, but an attempt to understand the 'triangulation' of three views: a mechanist, or 'enhanced mechanist' view in which one can work upwards, step by step from the basic property of irritability to the higher-level property of sensibility (Haller); a vitalist view in which sensibility is fundamental, matching up with a conception of the organism as the sum of parts conceived as little lives (Bordeu et al.); and, more eclectic, a materialist view which seeks to combine the mechanistic, componential rigour and explanatory power of the Hallerian approach, with the monistic and metaphysically explosive potential of the vitalist approach (Diderot). As we have seen, the

\footnotetext{
${ }^{87}$ Diderot, letter to Duclos of October 10 1765, Correspondance, vol. 5, p. 141.

${ }^{88}$ Diderot, 'Inné', Enc. vol.8, p. 754a; d'Holbach, Système de la nature, I, xiii, in CEuvres philosophiques, vol.1, p. 322.
} 
relation between the medical-vitalist approach to sensibility and Diderot's appropriation and transformation of that approach, is not one that lets itself be labelled easily, although his conceptual innovation in developing what Anne Vila calls the 'superproperty' of irritability and sensibility taken as a whole, ${ }^{89}$ is undeniable. In the 'laboratory' of the animal which forms the metaphysical horizon of the embodied materialist, 'sentir, c'est vivre'. 90

\section{Acknowledgments}

Thanks to Alexandre Métraux for his critical remarks.

\section{References}

Ian Alexander, 'Philosophy of Organism and Philosophy of Consciousness in Diderot's Speculative Thought', in Studies in Romance Philology and French Literature Presented to John Orr (Manchester, 1953), p. 1-21

Paul-Joseph Barthez, Nouveaux éléments de la science de l'homme, $1^{\text {st }}$ edition, Montpellier, Jean Martel aîné, 1778

Paul-Joseph Barthez, Nouveaux éléments de la science de l'homme, $2^{\text {nd }}$ edition (Paris, Goujon \& Brunot, 1806)

Yvon Belaval, Études sur Diderot (Paris, 2003)

Théophile de Bordeu, Euvres complètes, précédées d'une Notice sur sa vie et ses ouvrages par Monsieur le Chevalier de Richerand, 2 vols. (Paris, Caille et Ravier, 1818)

Dominique Boury, 'Irritability and Sensibility: Two key concepts in assessing the medical doctrines of Haller and Bordeu', Science in Context 21:4 (2008), p. 521-535

Etienne Bonnot de Condillac, Traité des sensations et Traité des animaux (Paris, 1984)

Tobias Cheung, 'Omnis Fibra Ex Fibra: Fibre Architectures in Bonnet's and Diderot's Models of Organic Order', Early Science and Medicine 15 (2010), p. 66-104.

Jacques Chouillet, Diderot poète de l'énergie (Paris, 1984)

Denis Diderot, Correspondance, ed. Georges Roth, 9 vols. (Paris, 1955-1961)

Denis Diderot, Éléments de physiologie, ed. Jean Mayer (Paris, 1964)

Denis Diderot, Euvres complètes, eds. Herbert Dieckmann, Jacques Proust, Jean Varloot (Paris, 1975-)

Denis Diderot, Euvres, ed. Laurent Versini, vol.1 : Philosophie (Paris, 1994)

François Duchesneau, La physiologie des lumières. Empirisme, modèles, théories (The Hague, 1982)

\footnotetext{
${ }^{89}$ Vila, Enlightenment and Pathology, p. 15.

${ }^{90}$ Diderot, Éléments de physiologie, in Euvres, vol.17, p. 447.
} 
François Duchesneau, 'Diderot et la physiologie de la sensibilité', Dix-huitième siècle 31 (1999), p. $195-216$

Colas Duflo, 'Sensibilité', in L'Encyclopédie du Rêve de D'Alembert de Diderot, eds. JeanClaude Bourdin, Colas Duflo et al. (Paris, 2006), p. 347-352

Charles-Louis Dumas, Principes de physiologie, ou introduction à la science expérimentale, philosophique et médicale de l'homme vivant, 2 vols. (Paris, Crapelet, 1806)

Encyclopaedia Londinensis, or, Universal dictionary of arts, sciences, and literature, ed. John Wilkes, vol. 1 (London, Adlard, 1810)

Henri Fouquet, 'Sensibilité, Sentiment (Médecine)', Encyclopédie ou Dictionnaire raisonné des arts et des métiers, eds. Denis Diderot and Jean Le Rond D’Alembert, 35 vols. (Paris, Briasson, David, Le Breton \& Durand, 1751-1780 ; reprint, Stuttgart/Bad Cannstatt, 1966), vol. 15, p. 3852

Henri Fouquet, Discours sur la clinique (Montpellier, Izar \& Ricard, 1803 [an XI])

Roger K. French, Robert Whytt, The Soul and Medicine (London, 1969)

Brian Garrett, 'Vitalism and teleology in the natural philosophy of Nehemiah Grew', British Journal for the History of Science 36 (2003), p. 63-81

Guido Giglioni, 'What ever happened to Francis Glisson? Albrecht Haller and the fate of eighteenth-century irritability', Science in Context 21:4 (2008), p. 465-493.

'D.G.' (Jean-Charles-Marguerite-Guillaume de Grimaud), Essai sur l'irritabilité (Avignon, Bonnet frères, 1776)

Elizabeth L. Haigh, Xavier Bichat and the medical theory of the eighteenth century, Medical History Supplement (London: Wellcome Institute for the History of Medicine, 1984)

Albrecht von Haller, A Dissertation on the Sensible and Irritable Parts of Animals (London, J. Nourse, 1755; reprint, Baltimore, 1936)

Albrecht von Haller, Mémoires sur la nature sensible et irritable des parties du corps animal, 4 vols. (Lausanne, Bousquet, 1756-1760)

Albrecht von Haller, Primae lineae physiologiae (originally published 1747), $3^{\mathrm{d}}$ revised and expanded edition (Göttingen: Ap. Vid. Ae. Vandenhoeck, 1765)

Albrecht von Haller, 'Sensibilité', Supplément à l'Encyclopédie, ou dictionnaire raisonné des sciences, des arts et des métiers, par une société de gens de lettres, 4 vols. (Amsterdam, M.-M. Rey, 1776-1777), vol.4 (1777), p. 776a-779b

Albrecht von Haller, First lines of physiology, Translated from the correct Latin edition printed under the inspection of William Cullen (Edinburgh, printed [by Macfarquhar and Elliot] for Charles Elliot, 1779)

Paul-Henri-Thiry, Baron d'Holbach, Système de la Nature ou des lois du monde physique et du monde moral (1770, 2 1781), in d'Holbach, Euvres philosophiques, ed. J.-P. Jackson, vol. 1 (Paris, 1998)

Philippe Huneman, “Animal Economy': Anthropology and the Rise of Psychiatry from the Encyclopédie to the Alienists', in The Anthropology of the Enlightenment, eds. Larry Wolff and Marco Cipolloni (Stanford, 2007), p. 262-276, 390-394 (notes) 
Timo Kaitaro, ' Man is an admirable machine' - a dangerous idea ?' in La lettre de la Maison française d'Oxford 14 (2001), special issue on Mécanisme et vitalisme, p. 105-121.

Julien Offray de La Mettrie, L'Homme-Machine (Leiden, E. Luzac, 1748)

Julien Offray de La Mettrie, L'Homme-Machine, ed. A. Vartanian (Princeton, 1960)

Émile Littré, 'De la physiologie', Revue des deux mondes 14 (1846), p. 200-237

Jean-Joseph Ménuret de Chambaud, 'CEconomie Animale (Médecine)', Encyclopédie ou Dictionnaire raisonné des arts et des métiers, eds. Denis Diderot and Jean Le Rond D'Alembert, 35 vols. (Paris, Briasson, David, Le Breton \& Durand, 1751-1780 ; reprint, Stuttgart/Bad Cannstatt, 1966), vol.9, 1765, p. 360-366.

Claude Perrault, Essais de physique ou recueil de plusieurs traitez touchant les choses naturelles (Paris, Jean-Baptiste Coignard, 1680), vol.1, $2^{\text {nde }}$ partie : Expériences pour l'Éclaircissement de la circulation de la sève des plantes

Peter Hanns Reill, Vitalizing Nature in the Enlightenment (Berkeley, 2005)

Roselyne Rey, Naissance et développement du vitalisme en France de la deuxième moitié du $18^{e}$ siècle à la fin du Premier Empire (Oxford, 2000)

Shirley A. Roe, 'Anatomia animata: the Newtonian physiology of Albrecht von Haller', in Transformation and tradition in the sciences: essays in honor of I. Bernard Cohen, ed. Everett Mendelsohn (Cambridge, 1984), p. 274-300

Otto Sonntag, ed., The correspondence between Albrecht von Haller and Charles Bonnet (Bern, 1983)

Hubert Steinke, Irritating Experiments. Haller's Concept and the European Controversy on Irritability and Sensibility, 1750-1790 (Amsterdam/New York, 2005)

Anne C. Vila, Enlightenment and Pathology. Sensibility in the Literature and Medicine of Eighteenth-Century France (Baltimore, 1998)

Kathleen Wellman, 'Materialism and vitalism', in The Oxford Companion to the History of Modern Science, ed. J.L. Heilbron (Oxford, 2003). Accessed at Oxford Reference Online.

September 15 2011. http://www.oxfordreference.com.

Robert Whytt, The Works of Robert Whytt (Edinburgh, Beckett and Balfour, 1768)

Charles T. Wolfe, 'Le rêve matérialiste, ou 'Faire par la pensée ce que la matière fait parfois', Philosophiques 34:2 (2007), p. 317-328.

Charles T. Wolfe, 'Endowed molecules and emergent organization: the Maupertuis-Diderot debate', Early Science and Medicine 15 (2010), p. 38-65; reprinted in T. Cheung, ed., Animals, Humans and Machines, 1600-1800 (Leiden, 2010)

Charles T. Wolfe, 'From substantival to functional vitalism and beyond, or from Stahlian animas to Canguilhemian attitudes', Eidos 14 (2011), p. 212-235

Charles T. Wolfe, 'Éléments pour une théorie matérialiste du soi', in La Circulation entre les savoirs au siècle des Lumières. Hommages à Francine Markovits, ed. François Pépin (Paris, 2011), p. 123-149. 